\title{
Induction of $\beta$-Lactamase in Proteus vulgaris
}

\author{
By KENJI OKONOGI, ${ }^{*}$ MITSUZO KUNO AND EIJI HIGASHIDE \\ Central Research Division, Takeda Chemical Industries Ltd, Yodogawa-ku, Osaka 532, Japan
}

(Received 30 April 1985; revised 20 August 1985)

\begin{abstract}
Various $\beta$-lactam antibiotics, including monocyclic $\beta$-lactams, induced the $\beta$-lactamase of Proteus vulgaris; when clinical isolates were induced by benzylpenicillin, each strain produced a single $\beta$-lactamase but the activity per milligram dry weight differed from strain to strain. The $\beta$ lactamases of the $P$. vulgaris strains were heterogeneous with respect to their isoelectric points, but had almost the same specific activities, substrate specificities and Michaelis constants. The kinetics of $\beta$-lactamase formation were investigated in three strains, each with a different $\beta$ lactamase activity. Differential rates of enzyme synthesis and peak activity depended on the concentration of inducer. The plots of the reciprocals of the differential rates versus the reciprocals of the inducer concentrations were linear, and the maximum rate of enzyme synthesis and the concentration of the inducer giving half-maximum induction were determined from this double reciprocal plot. The maximum rates of enzyme synthesis were different in the three strains. The kinetic analysis of $\beta$-lactamase formation revealed that the $\beta$-lactamase activities in a single bacterial species were determined by differences in the rate of enzyme synthesis and not by differences in the properties of the enzyme.
\end{abstract}

\section{INTRODUCTION}

Many $\beta$-lactamases, which are responsible for resistance to $\beta$-lactam antibiotics in pathogenic bacteria, are inducible enzymes (Richmond \& Sykes, 1973), and the mechanisms of induction have been studied by many investigators (Nordström \& Sykes, 1974; Sawai et al., 1977; Gootz \& Sanders, 1983). However, studies on the kinetics of induced $\beta$-lactamase formation in Gramnegative bacteria have been more difficult than those on $\beta$-galactosidase formation in Escherichia coli (Pardee \& Prestidge, 1961; Kepes, 1963; Boezi \& Cowie, 1961). One reason for this is a lack of appropriate gratuitous inducers (Jacob \& Monod, 1961), such as isopropylthiogalactoside and methyl-1-thio- $\beta$-D-galactoside for $\beta$-galactosidase, which themselves are not substrates of the enzyme. Another difficulty is the growth inhibitory properties of the $\beta$ lactamase inducers; several milligrams of an inducer antibiotic per millilitre are needed for maximum induction of $\beta$-lactamase in Gram-negative bacteria such as Pseudomonas aeruginosa (Sabath et al., 1965), Enterobacter cloacae (Minami et al., 1980), and Citrobacter freundii (Sawai et al., 1977), and growth is greatly impaired by these high concentrations of the antibiotic. The $\beta$ lactamase of Proteus vulgaris, however, can be induced by relatively low concentrations of $\beta$ lactam antibiotics (Okonogi et al., $1981 \mathrm{a}$ ) and hence $P$. vulgaris is a suitable organism for kinetic analysis of induced $\beta$-lactamase synthesis in Gram-negative bacteria.

This paper deals with the kinetics of $\beta$-lactamase formation by clinical isolates of $P$. vulgaris, each with different $\beta$-lactamase activity.

\section{METHODS}

Bacterial strains. Clinical isolates were identified using the API 20E System. The strains used in experiments on the kinetics of induction were suspended in Trypticase soy broth (TSB; obtained from BBL) containing $15 \%(v / v)$ glycerol and were stored at $-80^{\circ} \mathrm{C}$. 
Antibiotics. Sulfazecin, nocardicin A, carumonam (AMA-1080), C-19393 S, clavulanic acid, sulbactam, 6aminopenicillanic acid, and 7-aminocephalosporanic acid were prepared in our research division; aztreonam was from Hoffmann-La Roche and imipenem, nitrocefin and moenomycin were gifts from Merck, Glaxo and Hoechst, respectively. Other antibiotics were obtained from the following manufacturers: benzylpenicillin, ampicillin, sulbenicillin, mecillinam, cefsulodin, cefotiam and cefmenoxime from Takeda Chemical Industries, Japan; cloxacillin and cefazolin from Fujisawa Pharmaceuticals, Japan; cephaloridine and latamoxef from Shionogi, Japan; cefmetazole from Sankyo, Japan; cefoxitin from Daiichi Seiyaka, Japan; cefuroxime and ceftazidime from Glaxo, UK; cefoperazone and piperacillin from Toyama Chemical Industries, Japan; polymyxin B from Taito Pfizer, Japan; gramicidin S from Calbiochem, USA; bacitracin from Sigma and fosfomycin and cycloserine from Meiji Seika, Japan.

Susceptibility testings. The minimum inhibitory concentration (MIC) was determined by the standard agar dilution method using Trypticase soy agar (BBL). About $5 \mu \mathrm{l}$ of bacterial suspension containing about $10^{6}$ colony forming units $\mathrm{ml}^{-1}$ was inoculated with a multiple inoculator (Sakuma, Tokyo, Japan) onto agar plates containing twofold serial dilutions of each antibiotic. The plates were incubated at $37^{\circ} \mathrm{C}$ for $18 \mathrm{~h}$, and the MIC was defined as the lowest concentration of the drug on which there was either no visible growth or less than four colonies per spot.

Induction experiment. The $\beta$-lactamase activity of $P$. vulgaris $\mathrm{GN} 4818$ induced by $0 \cdot 1 \mathrm{mg}$ of various antibiotics $\mathrm{ml}^{-1}$ for $1 \mathrm{~h}$, and the activity of clinical isolates induced by $0.1 \mathrm{mg}$ benzylpenicillin $\mathrm{ml}^{-1}$ for 40 min, were

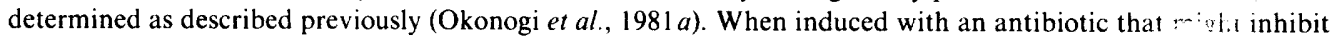
the enzyme, the enzyme preparation was dialysed extensively against $0.05 \mathrm{M}$-phosphate buffer ( $\mathrm{pH}$ ) before the enzyme was assayed. To analyse the kinetics of $\beta$-lactamase formation, $5 \times 10^{8}$ cells stored at $-80^{\circ} \mathrm{C}$ were inoculated into $10 \mathrm{ml} \mathrm{TSB}$ in an L-tube, and incubated at $37^{\circ} \mathrm{C}$ with shaking. An inducer was added when the $\mathrm{OD}_{600}$ of the culture reached 1 , and the incubation was continued. At 5 or 10 min intervals after induction, $0.75 \mathrm{ml}$ of the culture was withdrawn and added to the same volume of $0.05 \mathrm{M}-\mathrm{Na}_{2} \mathrm{HPO}_{4} / \mathrm{KH}_{2} \mathrm{PO}_{4}$ buffer (pH 6.9) containing $50 \mu \mathrm{g}$ chloramphenicol $\mathrm{ml}^{-1}$ in an ice bath, and the cells were disrupted at $2 \mathrm{~A}$ for $1 \mathrm{~min}$ with an ultrasonic disintegrator (Kaijo Denki, Japan). The disrupted cell suspension was used to determine enzyme activity with $0.2 \mathrm{~mm}$-cephaloridine as a substrate. Culture density was measured as $\mathrm{OD}_{600}$ with a Gilford 250 spectrophotometer. One $\mathrm{OD}_{600}$ unit corresponds to $0.45 \mathrm{mg}$ dry weight cells $\mathrm{ml}^{-1}$ (this value is the mean of ten representative clinical isolates which differed by less than $5 \%$ ).

Enzyme assay. $\beta$-Lactamase activity was determined micro-iodometrically and spectrophotometrically as described previously (Okonogi et al., $1981 \mathrm{a}$ ). $V_{\operatorname{mix}}$ and $K_{\mathrm{m}}$ were determined from Lineweaver Burk plots. One unit (U) of $\beta$-lactamase was defined as the amount of enzyme that hyrolysed $1 \mu$ mol cephaloridine $\min ^{-1}$ at $30^{\circ} \mathrm{C}$.

Purification of $\beta$-lactamase. Overnight cultures $(15 \mathrm{ml})$ of $P$. vulgaris GN4818, GN4413 or TN1945 were inoculated into $320 \mathrm{ml}$ Brain Heart Infusion broth (Difco) in litre flasks, and the flasks were shaken for $2 \mathrm{~h}$ on a rotary shaker at $30^{\circ} \mathrm{C}$. Benzylpenicillin $\left(0.5 \mathrm{mg} \mathrm{ml}^{-1}\right)$ was added to induce $\beta$-lactamase and incubation was continued for an additional $2 \mathrm{~h}$. Cells harvested from 21 of culture broth were suspended in $100 \mathrm{ml} 0.01 \mathrm{M}$-sodium phosphate buffer ( $\mathrm{pH} \mathrm{6.0)}$ ), and disrupted at $2 \mathrm{~A}$ for $3 \mathrm{~min}$ with an ultrasonic disintegrator in an ice bath. The crude enzyme solution obtained by removing cell debris by centrifugation at $30000 \mathrm{~g}$ for $30 \mathrm{~min}$ was dialysed against $0.02 \mathrm{M}$-sodium phosphate buffer ( $\mathrm{pH} 6.0$ ), and applied to a CM-Sephadex C-50 column $(1.6 \times 13 \mathrm{~cm})$ equilibrated with the same buffer. The enzyme was eluted with a linear gradient of $\mathrm{NaCl}(0-0.5 \mathrm{M})$ in the phosphate buffer. Fractions with activity were lyophilized, dissolved in water, and subjected to Sephadex G-100 gel filtration $\left(2 \times 95 \mathrm{~cm}\right.$ column) using $0.05 \mathrm{M}-\mathrm{Na}_{2} \mathrm{HPO}_{4} / \mathrm{KH}_{2} \mathrm{PO}_{4}$ buffer $(\mathrm{pH} 6.9)$.

Preparation of antiserum. Antiserum against the $\beta$-lactamase previously purified from $P$. vulgaris GN4413 (Okonogi et al., 1981a) was prepared as follows. Mice (6-week-old female BALB/C) were immunized subcutaneously with $0.2 \mathrm{ml}$ of an emulsion containing $100 \mu \mathrm{g}$ enzyme and Freund's complete adjuvant (Difco) on day 0 ; they were then immunized (boosted) intraperitoneally with $0.2 \mathrm{ml}$ of emulsion containing $10 \mu \mathrm{g}$ enzyme and $2 \mathrm{mg}$ aluminum hydroxide, and with $0.1 \mathrm{ml}$ of emulsion containing $50 \mu \mathrm{g}$ enzyme and Freund's incomplete adjuvant (Difco) on days 14 and 28 , respectively. The mice were bled on day 42 and the serum was stored at $-20^{\circ} \mathrm{C}$ until used.

Analytical isoelectric focusing. This was done at $20^{\circ} \mathrm{C}$ with a constant voltage of $200 \mathrm{~V}$ for $5 \cdot 5 \mathrm{~h}$ on a $14 \mathrm{~cm}$ cylindrical polyacrylamide gel (Wrigley, 1971), consisting of $5 \%(\mathrm{w} / \mathrm{v})$ acrylamide (Bio-Rad), $0 \cdot 25 \%(\mathrm{w} / \mathrm{v}) \mathrm{N}, N^{\prime}-$ methylenebisacrylamide (Wako, Japan), $0.56 \mu l \mathrm{~N}, N, N^{\prime}, N^{\prime}$-tetramethylethylenediamine $\mathrm{ml}^{-1}$ (Wako), $0.21 \mathrm{mg}$ ammonium persulphate $\mathrm{ml}^{-1}$ (Wako) and $2 \%(\mathrm{w} / \mathrm{v}) \mathrm{pH} 3 \cdot 5-10$ ampholine (LKB). The anode solution was $20 \mathrm{~mm}-$ phosphoric acid and the cathode solution $1 \mathrm{M}$-sodium hydroxide. The enzyme was detected by laying a filter paper, which had been dipped in a solution of $0.5 \mathrm{mg}$ nitrocefin $\mathrm{ml}^{-1}$, over the surface of the gel. To measure $\mathrm{pH}$, the gel was sliced into 14 pieces and each piece was incubated in $0.9 \mathrm{ml}$ water at $30^{\circ} \mathrm{C}$ for $2 \mathrm{~h}$.

Determination of molecular weight and purity of $\beta$-lactamase. The purified $\beta$-lactamases were analysed by SDSPAGE (Laemmli \& Favre, 1973) and the gels were stained for proteins with $0.1 \%$ Coomassie brilliant blue. Cytochrome C, chymotrypsinogen A, ovalbumin and BSA (Boehringer-Mannheim) were used as molecular weight standards. The proteins were quantified by densitometry of the gels with a Shimadzu CS-910 dualwavelength TLC scanner.

Protein determination. Protein was assayed by the Lowry method, using BSA as a standard. 
Table 1. Induction of $\beta$-lactamase by $\beta$-lactam antibiotics in P. vulgaris $G N 4818$

\begin{tabular}{|c|c|c|c|}
\hline Inducer $\left(100 \mu \mathrm{g} \mathrm{ml}^{-1}\right)$ & $\begin{array}{c}\beta \text {-Lactamase } \\
\text { activity after I h } \\
{\left[\mathrm{U}(\mathrm{mg} \text { dry weight })^{-1}\right]}\end{array}$ & Inducer $\left(100 \mu \mathrm{g} \mathrm{ml}^{-1}\right)$ & $\begin{array}{c}\beta \text {-Lactamase } \\
\text { activity after } 1 \mathrm{~h} \\
{\left[\mathrm{U}(\mathrm{mg} \text { dry weight })^{-1}\right]}\end{array}$ \\
\hline None & $0 \cdot 002$ & Monocyclic $\beta$-lactams & \\
\hline Penicillins & & Nocardicin A & $0 \cdot 264$ \\
\hline 6-Aminopenicillanic acid & $0 \cdot 192$ & Sulfazecin & $0 \cdot 343$ \\
\hline Benzylpenicillin & $0 \cdot 724$ & Carumonam & $0 \cdot 122$ \\
\hline Ampicillin & 0.457 & Aztreonam & $0 \cdot 269$ \\
\hline Sulbenicillin & 0.529 & Carbapenems & \\
\hline Cloxacillin & $0 \cdot 016$ & Imipenem & 0.463 \\
\hline Mecillinam & $0 \cdot 169$ & $\mathrm{C}-19393 \mathrm{~S}_{2}$ & $<0.001$ \\
\hline Piperacillin & $0 \cdot 141$ & Others & \\
\hline Cephalosporins & & Clavulanic acid & $0 \cdot 027$ \\
\hline 7-Aminocephalosporanic acid & $0 \cdot 153$ & Sulbactam & $0 \cdot 164$ \\
\hline Cephaloridine & 0.698 & & \\
\hline Cefazolin & $0 \cdot 507$ & & \\
\hline Cefsulodin & 0.650 & & \\
\hline Cefotiam & $0 \cdot 819$ & & \\
\hline Cefuroxime & 0.555 & & \\
\hline Cefmenoxine & 1.060 & & \\
\hline Ceftazidime & 0.993 & & \\
\hline Cefoperazone & $0 \cdot 038$ & & \\
\hline Cefoxitin & 0.627 & & \\
\hline Cefmetazole & 0.621 & & \\
\hline Latamoxef & 0.319 & & \\
\hline
\end{tabular}

\section{RESULTS}

Induction of $\beta$-lactamase by various antibiotics

The $\beta$-lactamase of $P$. vulgaris GN4818 was induced by various antibiotics and the activities were determined after dialysis (Table 1). When induced by antibiotics such as cefoxitin, clavulanic acid, sulbactam and $\mathrm{C}-19393 \mathrm{~S}_{2}$ which inhibit the $\beta$-lactamase, the activities were negligible or quite low, but they were increased remarkably by dialysing the enzyme preparations except that induced by $\mathrm{C}-19393 \mathrm{~S}_{2}$, which has a strong $\beta$-lactamase-inactivating activity (Okonogi et al., $1981 \mathrm{~b}$ ). Dialysis had no effect on the activity of $\beta$-lactamase after induction with antibiotics having no $\beta$-lactamase-inhibitory activity. Benzylpenicillin, ampicillin, sulbenicillin and most cephalosporins were good inducers of the $\beta$-lactamase. Imipenem and monocyclic $\beta$-lactam antibiotics, such as sulfazecin and aztreonam, also had relatively high activity as inducers. Cloxacillin, cefoperazone, and clavulanic acid were poor inducers. Bicyclic amino acids, reported to induce the $\beta$-lactamase of Enterobacter cloacae strain 996/81 (Cullmann et al., 1984), and non- $\beta$-lactam antibiotics, which inhibit cell wall synthesis or membrane functions, such as bacitracin, fosfomycin, meonomycin, cycloserine, polymyxin B and gramicidin $\mathrm{S}$, did not induce the $P$. vulgaris $\mathrm{GN} 4818 \beta$-lactamase.

\section{$\beta$-Lactamase activity in clinical isolates}

$\beta$-Lactamase activities were determined in clinical isolates of $P$. vulgaris having different susceptibilities to cephalosporins (Table 2 ). All strains produced only very small amounts of $\beta$ lactamase without an inducer, but produced much more enzyme after induction by $0.1 \mathrm{mg}$ benzylpenicillin $\mathrm{ml}^{-1}$. Each strain produced a single $\beta$-lactamase; only one activity band was detected on polyacrylamide gel after isoelectric focusing. The $\beta$-lactamases of $P$. vulgaris were heterogeneous with respect to their isoelectric points and the induced activity also varied from strain to strain, though the substrate specificities of the enzymes were almost the same. There was no correlation between the activities and the isoelectric points of the $\beta$-lactamases. Most strains were highly sensitive to cefmenoxime, though some with high $\beta$-lactamase activity were slightly less sensitive. Resistance to cefotiam was related to the $\beta$-lactamase activity. All strains were resistant to cefazolin. 


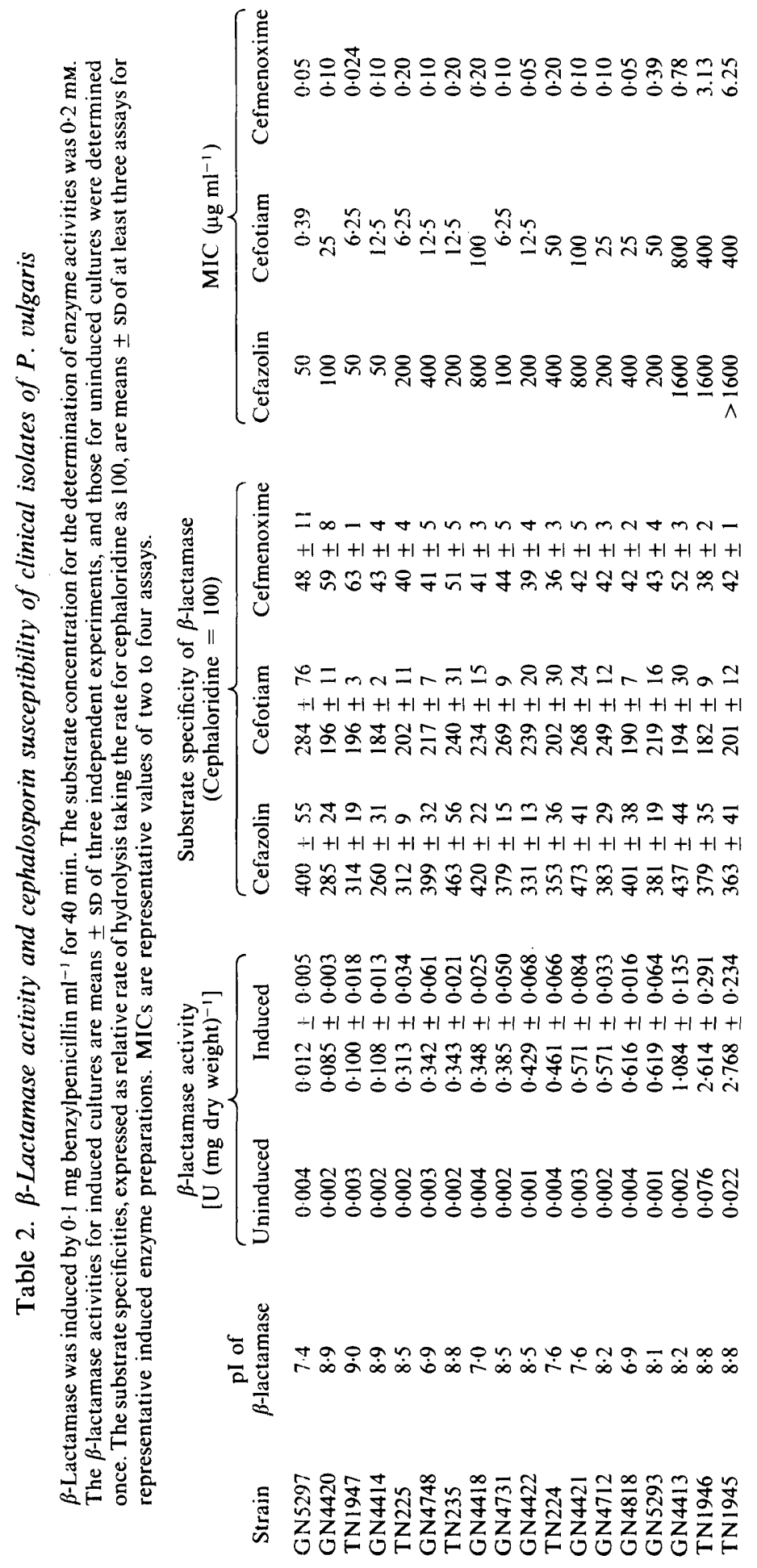




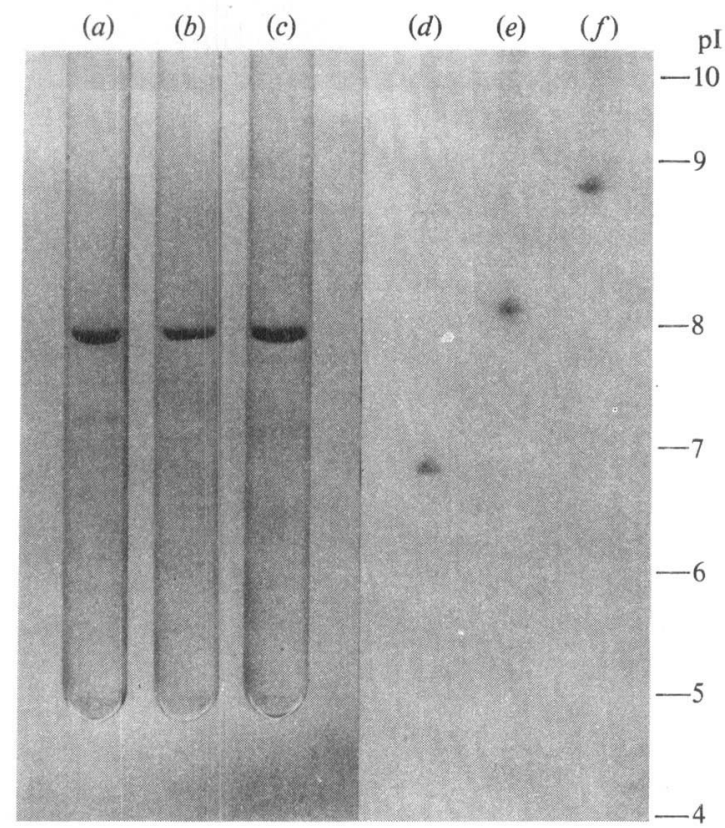

Fig. 1. SDS-PAGE $(a-c)$ and isoelectric focusing $(d-f)$ of $P$. vulgaris $\beta$-lactamases. $(a)$ and $(d)$ GN4818; $(b)$ and $(e)$ GN4413; $(c)$ and $(f)$ TN1945.

Table 3. Properties of $\beta$-lactamases purified from P. vulgaris GN4818, GN4413 and TN1945

$\begin{array}{lccc} & \text { GN4818 } & \text { GN4413 } & \text { TN1945 } \\ \text { Molecular weight }( \pm \text { the range }) & 27000 \pm 1000 & 27500 \pm 1000 & 28000 \pm 1000 \\ \text { Specific activity* }\left[V_{\text {max }}, \mu \mathrm{mol} \mathrm{min}^{-1}(\mathrm{mg} \text { protein })^{-1}\right] & & & 559 \\ \text { Cephaloridine } & 522 & 556 & 704 \\ \text { Cephalothin } & 712 & 840 & 1719 \\ \text { Cefazolin } & 2434 & 2641 & 1179 \\ \text { Cefotiam } & 1468 & 1485 & 229 \\ \text { Cefmenoxime } & 293 & 339 & 49 \\ \text { Benzylpenicillin } & 51 & 57 & 127 \\ K_{\mathrm{m}}(\mu \mathrm{M}) & & 118 & 39 \\ \text { Cephaloridine } & 105 & 31 & 89 \\ \text { Cephalothin } & 30 & 103 & 143 \\ \text { Cefazolin } & 111 & 228 & 138 \\ \text { Cefotiam } & 161 & 150 & 4.4 \\ \text { Cefmenoxime } & 154 & 6.8 & \end{array}$

* The values were corrected by considering the purities of the enzyme preparations $(90,96$ and $99 \%$ for the enzymes of $P$. vulgaris GN4818, GN4413 and TN1945, respectively).

\section{Properties of $\beta$-lactamases}

$\beta$-Lactamases were purified from $P$. vulgaris GN4818, GN4413 and TN1945, which have different $\beta$-lactamase activity and susceptibility to cephalosporins, and the properties of the enzymes were compared. The $\beta$-lactamases were purified more than 120 -fold by the two-step purification procedure. The purities of the enzyme preparations from $P$. vulgaris GN4818, GN4413 and TN1945 were 90,96 and $99 \%$, respectively. The three enzymes had different isoelectric points (Fig. 1) and showed slightly different responses to inhibition by antiserum (Fig. 2). However, their specific activities, Michaelis constants for six substrates and molecular weights were all very similar (Table 3 ). 


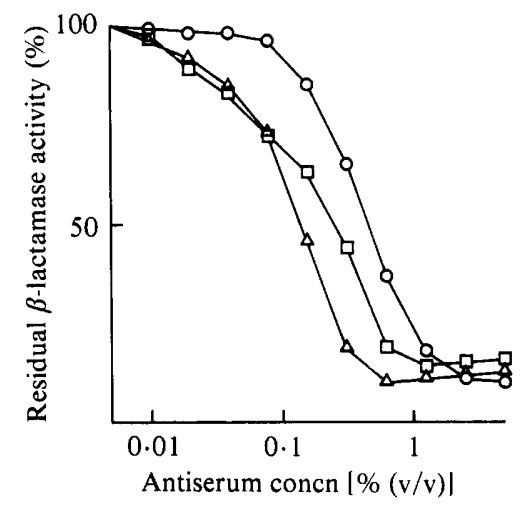

Fig. 2

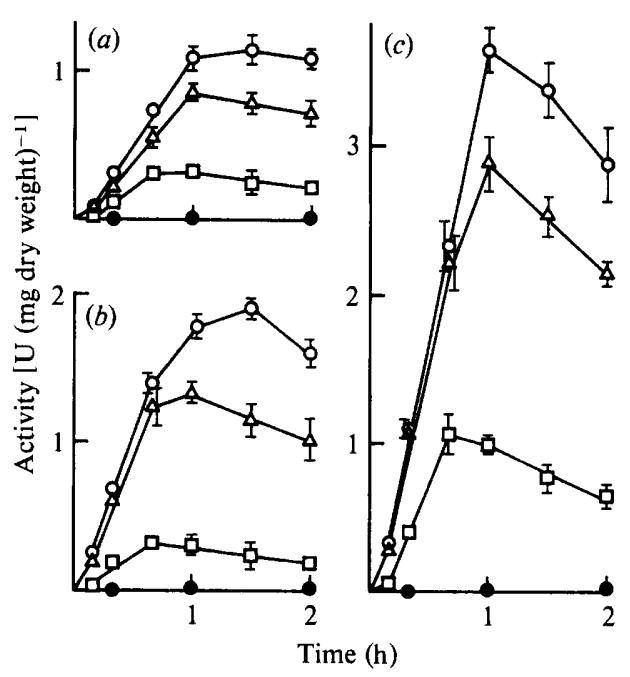

Fig. 3

Fig. 2. Inhibition of $\beta$-lactamase of $P$. vulgaris by antiserum. The $\beta$-lactamases from $P$. vulgaris GN4818 (O), GN4413 $(\triangle)$ and TN $1945(\square)$ were incubated with anti-P. vulgaris GN4413 $\beta$-lactamase serum for $1 \mathrm{~h}$ at $37^{\circ} \mathrm{C}$, before enzyme assay. The results are the means of three determinations which differed by less than $10 \%$.

Fig. 3. Induction of $\beta$-lactamase of $P$. vulgaris GN4818 (a), GN4413 (b) and TN1945 (c). The $\beta$ lactamase was induced by $1(\bigcirc), 10(\square), 100(\triangle)$ and $1000(\bigcirc) \mu \mathrm{g}$ benzylpenicillin $\mathrm{ml}^{-1}$. The results are the means of two determinations; bars indicate \pm the range.

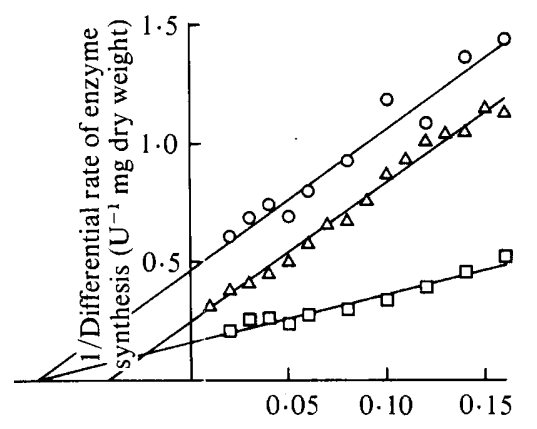

1/Benzylpenicillin concn $\left(\mu \mathrm{g}^{-1} \mathrm{ml}\right)$

Fig. 4. Double reciprocal plot for $\beta$-lactamase induction. The differential rate of enzyme synthesis (increase in $\beta$-lactamase activity per increase in cell mass) in $P$. vulgaris GN4818 (O), GN4413 $\triangle$ ) and TN1945 ( $\square$ ) was determined by assaying the enzyme activity and the cell mass of the culture at 5 or $10 \mathrm{~min}$ intervals after induction as described in the text. Linear regression equations were estimated by the method of least squares; correlation coefficients were $0.97,0.99$ and 0.97 for $P$. vulgaris GN4818, GN4413 and TN1945, respectively.

\section{Kinetics of $\beta$-lactamase production}

The specific activity of $\beta$-lactamase after induction was determined in $P$. vulgaris GN4818, GN4413 and TN1945 (Fig. 3). When benzylpenicillin was added as an inducer to bacteria growing exponentially, $\beta$-lactamase synthesis began after a 5 to $10 \mathrm{~min}$ lag time, and continued at a constant rate for at least $20 \mathrm{~min}$. As the inducer concentration was increased, the lag time decreased and the period of enzyme synthesis increased. The enzyme synthesis stopped $1 \mathrm{~h}$ after the addition of $1 \mathrm{mg}$ benzylpenicillin $\mathrm{ml}^{-1}$, probably because of depletion of the antibiotic by hydrolysis. The rate of enzyme synthesis during the early phase and the peak levels of the activity depended on the concentration of the inducer (Fig. 3). Differential rates of enzyme 
synthesis (increase in enzyme activity divided by increase in cell mass) were determined after induction with various concentrations of benzylpenicillin. The relationship between the differential rate and the inducer concentration was similar to that between the reaction velocity and the substrate concentration in the enzyme reaction, and a plot of the reciprocal of the differential rates against the reciprocal of the concentrations of the inducer was found to be linear (Fig. 4). From this double reciprocal plot, the maximum rate of enzyme synthesis and the concentration of the inducer giving half-maximum induction were determined in the same way as are $V_{\max }$ and $K_{\mathrm{m}}$ by the Lineweaver-Burk method. The maximum rates of enzyme synthesis in P. vulgaris GN4818, GN4413 and TN1945 were estimated to be $2 \cdot 1,4 \cdot 2$ and $6 \cdot 2 \mathrm{U}$ (mg dry weight $)^{-1}$, respectively. The concentration of benzylpenicillin giving half-maximum induction was $12.7 \mu \mathrm{g} \mathrm{ml}^{-1}$ in P. vulgaris GN4818 and TN1945, and $25.5 \mu \mathrm{g} \mathrm{ml}^{-1}$ in P. vulgaris GN4413.

\section{DISCUSSION}

Induced $\beta$-lactamase formation in Gram-negative bacteria is considered to be controlled negatively by a repressor (Nordström \& Sykes, 1974; Sawai et al., 1977; Gootz \& Sanders, 1983); the enzyme can be induced by various penicillins, cephalosporins (Minami et al., 1980) and a carbapenem antibiotic (Grappel et al., 1984). The present work has demonstrated that monocyclic $\beta$-lactam antibiotics are also inducers of $\beta$-lactamase. It has been reported that some bicyclic amino acids, and complex media such as TSB and Schaedler's broth, induced the $\beta$ lactamase of Enterobacter cloaceae strain 996/81 (Cullmann et al., 1984), and that bacitracin, a non- $\beta$-lactam antibiotic, induced the $\beta$-lactamase of Bacillus cereus (Citri, 1978), but such nonspecific induction did not occur in $P$. vulgaris. These results suggest that the repressor of the $\beta$ lactamase of $P$. vulgaris recognizes the $\beta$-lactam structure only. A lack of enzyme activity after induction by $\mathrm{C}-19393 \mathrm{~S}_{2}$ may be due to potent $\beta$-lactamase-inactivating activity (Okonogi et al., $1981 \mathrm{~b}$ ) rather than to lack of inducer activity of the antibiotics; the fact that the enzyme activity after induction by $\mathrm{C}-19393 \mathrm{~S}_{2}$ was lower than the basal level supports this assumption.

When induced with a given concentration of benzylpenicillin, the activity of $\beta$-lactamase in clinical isolates of $P$. vulgaris varied greatly from strain to strain. The different activites could result from a difference in either (i) the specific activities of the enzymes, (ii) the periods of $\beta$ lactamase synthesis after induction, (iii) the rate of enzyme synthesis or (iv) the concentration of inducer required for maximum induction. However, the enzymes purified from three strains with different total activity had almost the same specific activity. Also, the period during which enzyme synthesis continued depended only on the concentration of inducer, and was almost the same in the three strains. Therefore, both reasons (i) and (ii) can be disregarded.

Possibilities (iii) and (iv) were investigated by a kinetic analysis of $\beta$-lactamase induction. Boezi \& Cowie (1961), and Müller-Hill et al. (1964) reported that the reciprocals of the specific $\beta$ galactosidase activities of $E$. coli induced by methyl-1-thio- $\beta$-D-galactoside were proportional to the reciprocals of the square of the inducer concentrations. The reciprocals of the differential rates of $\beta$-lactamase synthesis in $P$. vulgaris were proportional to the reciprocals of the inducer concentrations, and not to the reciprocals of their squares. The maximum rates of enzyme synthesis obtained from the double reciprocal plots were different in the three strains, and the concentrations of the inducer giving half-maximum induction were independent of enzyme activity, indicating that the strains with high activity synthesize the enzyme protein at a higher rate than those with low activity. Differences in the rate of enzyme synthesis would result from differences in either the efficiency of the $\beta$-lactamase promoter or the number of $\beta$-lactamase genes.

The $\beta$-lactamases of the $P$. vulgaris strains differed in their isoelectric points, indicating that there are some variations in their amino acid composition, which might have resulted either from mutations in the $\beta$-lactamase gene or from different post-translational processing in the different strains. The changes in amino acid composition need only be small; plasmid-mediated TEM-1 and TEM-2 $\beta$-lactamases, which have different isoelectric points, differ by only a single amino acid (Ambler, 1978; Sutcliff, 1978). Alternatively, some amino acids may be lacking in some $\beta$-lactamases; the $\beta$-lactamases of $P$. vulgaris $\mathrm{GN} 4818$ and GN4413 migrated slightly more 
quickly than that of TN1945 on SDS-polyacrylamide gel and Sephadex G-100 gel. Since the $\beta$ lactamase is a periplasmic protein and has a leader peptide, the latter possibility could result from different processing of the leader peptide as well as by mutational deletion within the $\beta$ lactamase gene. In any case, the structure of the active site must be conserved because the three enzymes had almost the same specific activities, substrate specificities and Michaelis constants. Slight differences in responses to antiserum may have resulted from differences in structure in the vicinity of the active site which altered binding affinity to antibody. Matthew et al. (1975) introduced analytical isoelectric focusing to identify $\beta$-lactamases, and suggested that the technique could be used in bacterial taxonomy (Matthew \& Harris, 1976). However, observations that the $\beta$-lactamases of clinically isolated $P$. vulgaris were heterogeneous with respect to their isoelectric point, indicate that the use of the isoelectric focusing of $\beta$-lactamases in taxonomy may be misleading.

We thank Dr S. Shiho for preparing the antiserum and Mrs E. Saga for her technical assistance. We also thank Drs Y. Nakao and M. Yoneda for their encouragement throughout this work.

\section{REFERENCES}

Ambler, R. P. (1978). Partial amino acid sequence of penicillinase coded by Escherichia coli plasmid R6K. Proceedings of the National Academy of Sciences of the United States of America 75, 3732-3736.

BoEZI, J. A. \& COWIE, D. B. (1961). Kinetic studies of $\beta$-galactosidase induction. Biophysical Journal 1, 639-647.

CITRI, Y. (1978). Induction of penicillinase by batcitracin. Biochemical and Biophysical Research Communications 80, 573-579.

Cullmann, W., Dalhoff, A. \& Dick, W. (1984). Nonspecific induction of $\beta$-lactamase in Enterobacter cloacae. Journal of General Microbiolog!' 130, $1781-1786$.

Gootz, T. D. \& Sanders, C. C. (1983). Characterization of $\beta$-lactamase induction in Enterohacter cloacae. Antimicrobial Agents and Chemotherapy 23, 91-97.

Grappel, S. F., Giovenella, A. J., Newmann, D. J. \& NisBET, L. J. (1984). $\beta$-Lactamase induction by $N$ formidoylthienamycin. Journal of Antibiotics 37, $1101-1102$.

JACOB, F. \& MONOD, J. (1961). Genetic regulatory mechanisms in the synthesis of proteins. Journal of Molecular Biology 3, 318-356.

KEPES, A. (1963). Kinetics of induced enzyme synthesis. Determination of the mean life of galactosidasespecific messenger RNA. Biochimica et biophysica acta 76, 293-309.

LaEmmli, U. K. \& FaVre, M. (1973). Maturation of the head of bacteriophage T4. I. DNA packaging events. Journal of Molecular Biology 80, 575-599.

MatTHEW, M. \& HarRIS, A. M. (1976). Identificalion of $\beta$-lactamases by analytical isoelectric focusing: correlation with bacterial taxonomy. Journal of General Microbiology 94, 55-67.

Matthew, M., Harris, A. M., Marshall, M. .. \& Ross, G. W. (1975). The use of analytical isoelectric focusing for detection and identification of $\beta$ lactamases. Journal of General Microbiology 88, 169 . 178.

Minami, S., Yotsuji, A., Inoue, M. \& Mitsuhashi, S.
(1980). Induction of $\beta$-lactamase by various $\beta$-lactam antibiotics in Enterobacter cloacae. Antimicrobial Agents and Chemotherapy 18, 382-385.

MüLler-Hill, B., Rickenberg, H. V. \& Wallenfels, K. (1964). Specificity of the induction of the enzymes of the lac operon in Escherichia coli. Journal of Molecular Biology 10, 303-318.

Nordström, K. \& SyKes, R. B. (1974). Induction kinetics of $\beta$-lactamase biosynthesis in Pseudomonas aeruginosa. Antimicrobial Agents and Chemotherapy 6, 734-740.

Okonogi, K., Kuno, M., Kida, M. \& Mitsuhashi, S. $(1981 a) . \quad \beta$-Lactamase stability and antibacterial activity of cefmenoxime (SCE-1365), a novel cephalosporin. Antimicrobial Agents and Chemotherapy 20, 171-175.

OKonogi, K., Nozaki, Y., Imada, A. \& Kuno, M. (1981b). C-19393 $\mathrm{S}_{2}$ and $\mathrm{H}_{2}$, new carbapenem antibiotics. IV. Inhibitory activity against $\beta$-lactamases. Journal of Antibiotics 34, 212-217.

Pardee, A. B. \& Prestidge, L. S. (1961). The initial kinetics of enzyme induction. Biochimica et biophysica acta 49, 77-88.

Richmond, M. H. \& Sykes, R. B. (1973). The $\beta$ lactamase of Gram-negative bacteria and their possible physiological role. Advances in Microbial Physiology 9, 31-88.

Sabath, L. D., Jago, M. \& Abraham, E. P. (1965). Cephalosporinase and penicillinase activities of a $\beta$ lactamase from Pseudomonas pyocyanea. Biochemical Journal 96, 739-752.

Sawal, T., NaKajima, S., Morohoshi, T. \& YamaGISHI, S. (1977). Thermolabile repression of cephalosporinase synthesis in Citrobacter freundii. Microbiology and Immunology 21, 63I-638.

SutClifF, J. G. (1978). Nucleotide sequence of the ampicillin resistance gene of Escherichia coli plasmid pBR322. Proceedings of the National Academy of Sciences of the United States of America 75, 37373741.

WRIGLEY, C. W. (1971). Gel electrofocusing. Methods in Enzymology 22, 559-564. 